Metodički obzori 6(2011)2

Review article

UDK: 37.013 .2

Received: 21. 10. 2010.

\title{
COMPATIBILITY OF THE NARROWER AND WIDER ENVIRONMENT AS AN INSEPARABLE FACTOR OF MODERN MANAGEMENT OF LEARNING AND TEACHING
}

\author{
Bekir Makić, BA \\ Internacionalni univerzitet \\ Novi Pazar (Serbia) \\ e-mail: bmakic@gmail.com
}

\begin{abstract}
Sum mary
Personal characters of parents, educators, and other people who surround a child until adulthood are crucial for the correct upbringing of a child. Both parents have an influence on the mental and physical health of their child. Their harmonious relationship based on love and tolerance evokes feelings of satisfaction and happiness in a child. As the family grows bigger and more numerous, the responsibility of parents increases. New generations are not raised solely by the family.

Coincidentally, a child makes contacts and creates different relations with society through peers in the nursery school, pre-school, parks, playgrounds and later in school, groups, sections, and clubs.

Besides the parents and peer groups, other members of the family (brothers, sisters, grand parents) make influence in the formation of a child's personality.
\end{abstract} with others.

Key words: family, parents, living environment, influence, support, relations

\section{Introduction}

The personality of the parents, the people involved in the upbringing of the child, and all those by whom the child is surrounded in its growing up, are of crucial importance for the proper upbringing of the child. The formation of habits of children, their attitude toward themselves and the narrower and wider community are directly affected by the personal attitude of parents, their moral beliefs, intellection, manners, temperament, and personality. The quality of mental and physical health of children is affected by both parents. Their harmonious relationship based on love and tolerance directly creates a sense of satisfaction and happiness for the child.

"The family is the first environment where children receive impressions. In the family, the child acquires its first habits and develops its strengths and abilities. Parents give the child its first exposure to knowledge, and develop the child's interests and habits. Parents set the direction for the child in its observations and opinions; how the 
child will fit into a wider social environment is based on the parents' outlook and views" (Galevska 1961: 12).

Habits acquired in early childhood have a profound effect throughout life. It is for this reason that family education is of great importance. New generations are not raised solely by the family. The child, due to circumstances, enters into various relationships; it maintains contacts with society such as peers in the nursery, kindergarten, preschool, and the park, then later in school, assigned groups, sections, and clubs.

The more numerous the family, the more the responsibility of the parents is increased. In addition to parents and peer groups, the formation of the child's personality is affected by other members of the family, such as younger or older children, or grandparents. They, like the parents, exert a direct, but also indirect impact on the child. The family consists of adult members and children who join the family at birth. Different habits, jealousy that occurs at certain stages, the need to attract attention, and resulting aggression are just some of the side effects encountered by families with two or more children.

Therefore, love of the parents and other family members, which are an integral part of the modern society, is particularly important. The sense that children are loved and surrounded by care and safety during a healthy childhood is a prerequisite for forming a healthy child's personality.

\section{Impact of narrower social environment on education of children within contemporary society}

The first model that children are faced with in early childhood at a preschool age is certainly a parent. No matter what historical period we are talking about, the important influence of parents on the educational habits of children is the same - unique and inconceivable. What is different is the intensity of the impact on children. In fact, in modern society, the rapid pace and business deny parents the opportunity to parent; this has a clear and direct impact on the educational habits of their children. Instead, these are influenced by grandparents, educators, teachers, peers, media, etc.

A child who observes his parents learns from them, but also tries to imitate the parents in order to attract their attention, to receive praise, to avoid punishment, to prove himself to parents, or to outdo them in their skills.

Parents are the most important role models in early childhood, in preschool, and at an early school stage. How long the parent will retain the status as a parent "model" depends on the behaviour and status of parents. The influence of peer groups and the value system that they impose, in conjunction with the mass media, is crucial to the selection of children's idols. The main role models for children are parents. If a parent is not satisfied with the child's behaviour, the parent should certainly consider whether the child adopted such behaviour from the parents.

"A small child seeks to find a best friend in its own parents who will protect the child from unpleasantness, especially in early childhood. The parents introduced the child to life, helping it to get to know the world." (Galevska 1961:21). 
Messages that parents send their child, the expectations that they have, and the criteria for a system of values can become a serious problem in the behaviour of the child because the child sees these things, adopts them, and repeats them in everyday communication. When playing, children reflect the parents' behaviour.

Physical activity fosters the development and growth of the child; parents could start joint activities even while the child is still a baby. Parents encourage their children to be physically active and outdoors in nature, such as in parks, gardens, forests, and meadows; parents influence the development of a positive attitude towards physical activity in general, the relationship with the outside world, and themselves. Children whose parents rarely take them into nature (referring to children before puberty, when children already can independently implement this activity) have a weakened potential, their mental development is unsatisfactory, they become sluggish, lazy, emotionally depleted, and because of this, the first health problems appear. These are all consequences of the lack of physical activity (weak immune system, excess weight, poor respiratory capacity, a problem with posture from excessive sitting, flat soles, problems with concentration, etc.).

It is important for the parent to differentiate between a child's whims and his real wishes are. If a parent does not realize the needs of the child and does not provide help, it would be wrong on the parent's part to expect someone else to do it for them, or to make up for their failure (i.e.: the school).

The school as an institution, which is located in the external environment, will offer the child a variety of events and activities (number of clubs, cross-sport activities, competitions...). The fact that these activities offered to a child do not contain a clause of "compulsory attendance" means that it is expected that a withdrawn child, insecure child, or a shy child will not participate in those activities, and their potential talents will never develop. Therefore, it is important that families (parents, siblings, or grandparents who live in the same household) persist and support the child.

Grandparents who live in the same household with the child have more leisure time than they had when their children were small. In addition, they overcame the numerous dilemmas and bad experiences (such as fears) through the raising of their children. Caring for regular nutrition and safety in their presence is one of the positive facts in child development, coming from the immediate environment. "The biggest downside of the child staying with its grandparents is that it usually excludes the presence of other children." (Holcner 2005: 127)

Being too tolerant and meeting children's demands may be counterproductive for the child. Older siblings are a particular influence on the child; they are important elements coming from the immediate environment.

Parent set the prime examples for children and show them the proper attitudes; they also show respect for the rules and norms that are set within the family, and are objective and do not take sides, but try to be a real model of behaviour for their children. 


\section{Influence of wider environment on education in contemporary society}

In addition to parents who have the greatest influence in the upbringing of children, there are other factors which are of great importance: mass media, peer groups, sports associations, nongovernment organizations, and other humanitarian organizations. It is hard to tell which of these factors is more dominant.

Very often parents, whose role is to establish a system of values, are influenced by mass media. Mass media have the same or greater impact on peers (peer groups) at school. Prerequisites, affinities, abilities, parents, and peers influence the involvement of children in some sports clubs or in governmental and nongovernmental organizations.

If a child or parent has high expectations of professional results, they are at risk of serious disappointment and potential abandonment of the sport. The influence of coaches and a good cooperative relationship between parents and coaches is very important because it affects the formation of the child's personality. Both figures are an example and model behaviour for the child.

"Sport will help the aggressive child to learn to control its emotions and channel the energy to a socially acceptable level. Sport will encourage a shy child to relax in social situations and make a braggart step down to a realistic measure, giving them a sense that they no longer need to invent their own experiences in order to be accepted. "(Holcner 2005: 162)

An important part of children's growing up is the influence of peer groups. Experiences that a child gets in communication with other children are irreplaceable, and cannot be achieved within the family environment. Relations in peer groups that influence the formation of character, child behaviour and peer judgment range from a high of solidarity and compassion to cruel rejection.

Setting fashion trends, cheering for teams, music selection, bias (religious or any other kind), literature choice, commitment to sports or vices (cigarettes, drugs) are just some of the external elements that are formed under the influence of peer groups. Idols create imaginary ideals children aspire to, and their selection by the child sends parents a clear message about what the child wants to be.

Namely, in the $90 \mathrm{~s}$, influenced by the economic crisis and the blockade of our country, many parents had a minimum income or were losing their jobs. At the same time a new social class emerged with questionable moral backgrounds and luxurious lifestyles, which caused admiration from young people and adolescents. They soon became their idols. Parents became a laughing stock overnight, whose value system in children caused only resistance and resentment.

Common features of new idols have become material wealth, eccentric physical appearance, nationally emphasized and politically coloured status.

In secondary schools, older children have the greatest impact on the choice of models among peers and peer groups. At this age, children tend to frequently change idols, and parents should support children's decisions and frequent changes until the child has completed the teenage period.

The more a society is in crisis, the more a child grows in a disturbed system of social values and his idols are necessary to find and build his own way. 
What are the common criteria for the selection of idols? As a rule, there are different talents, such as the popularity of pop stars or sport success, and less noble are scholarly work and a sense of humour.

Most parents are concerned about their children identifying with toys, which are usually the main characters of favourite cartoons or comic books. The fear of parents is reflected in the attitude that aggressive heroes encourage aggression in children. This attitude is wrong. Aggression is manifested in children who do not watch the same movies or read a comic (i.e., they have the same "aggressive" idols). By playing with these toys, children display aggression through becoming absorbed in the role of its hero; this is temporarily cathartic for the child but the child retains aggressive habits. The criteria for the selection of toys by parents are completely different from that of children. Mostly through these games, children compensate for their personal fears that they cannot or do not manage to explain to their parents.

By purchasing the world's most popular toys for girls, Barbie dolls, parents emphasize the uniqueness of these toys: gorgeous curves, long blonde hair, with an expensive pink house, swimming pool, a Porsche... and so unconsciously set values for girls because they want to become a Barbie. Barbie becomes the idol for girls. Dolls for girls and boys (if they are a warrior, a powerful transformer, a strange creature from the imagination) are like living beings. The children give the dolls names, features, powers, and limitations. Dolls tolerate and withstand all that children do to them. The child is aware that this is only a puppet in their hands, ready to execute everything as imagined; parents, siblings, or friends cannot accept such demands. Idols no longer seem unattainable because children can play with them. Children become superheroes and identify with them in the fight for good (for example, Superman, Batman). Throughout the game these models will be rejected at a certain point when the child gets bored of the toy; the child will then choose a new idol (toy).

With each new action film and a popular, fresh hero, the promoters sell T-shirts with images of the heroes or a variety of prizes in many contests, which encourage identification with the hero. If we further add the prejudice of parents that children do not need to show emotions for every little thing ("boys don't cry" or "boys aren't afraid of the dark") to the coproduction with movie stars/idols, the parents unwittingly support the child to face its own feelings the same way the idol in the movie does; the children are wounded and lost, but they don't give up and seek an exit to the situation.

It is a big mistake when parents blame video games, cartoons, characters, and action movies for the aggressive behaviour of their children.

\section{Father as an educator (The role of fathers as educators in contemporary and traditional family)}

Both parents are important for a healthy development of children's potential. Children need a balance of authority in relation to the father's authority (or opposite, where the dominant role is the mother). A girl's father is necessary to build a proper relationship with the opposite (male) sex, and boys to identify with them and develop a pattern of conduct in relation to their own gender. 
Fathers tend to reduce the problem. Differences in educational access for fathers and mothers are often very positive, because they lead to a positive balance between reducing the problem of the fathers and exaggerating the problem of sensible mothers.

Fathers are most associated with their sons through various manifestations, actions, or common activities. A job son and father do together gives the son a chance to admire his father, helping him to be a friend. Fathers must take care that their relationship does not develop into criticism, and not to be frustrated by the child. Boys are by nature more goal-focused. When the boy realizes that he failed, he should know that his father was always available for help. The father should not always point out that his son could be noticeably better. If the father has more children, he must be aware of their differences. The father's task is to recognize what is good about his sons, to support them to persevere, to help them overcome the deficiencies and accept them as they are.

If the father establishes a harmonious relationship with his son and the control of the activities of the child does not have actions for the ultimate punishment, his son will not be afraid of his father's punishment and own potential mistakes.

As for the relation of a father and his daughters, the father has to put a lot of time into the relationship to be harmonious and loving. The inherent nature of female children is to talk a lot; they emphasize the need to be listened to by the father. In today's family, the father, who is the most substantive holder of income, is very busy and often has very little time to talk to his daughter in order to listen to her without offering the usual advice. This gives impression to the daughter that the father does not care for her and that he is not concerned about her problems.

Children, who grow up under the watchful eye and supervision of their father, have a greater chance to have a healthy development and to create a positive image of themselves. This does not apply to children whose parents are divorced, but to the children whose father abandoned them, fathers who do not take care of their children, who have passed away; in other words, fathers who have no contact with their children. Modern pedagogy advocates the view that in their development children who follow the father figure walk earlier, speak earlier, and are freer in communicating.

At a later age, these children adapt easier to kindergarten and school, they join peer group easier, they can accept authority figures easier, and they have a harmonious relationship with the girls, that is the opposite sex. With the growth of the child and the entrance into the period of adolescence, the father becomes an important interlocutor, a friend, and an adviser. During the education of the child, parents usually treat boys differently than girls (this is particularly present in rural areas) and this difference is reflected in their emotions. In order to protect their children, parents often do not give importance to feelings of hurt; that is how they minimize or exaggerate their wishes that their children do not experience childhood like they did themselves. Pedagogical services in the schools or other institutions, often recorded, that the expression of emotions for boys is denied by the father. Emotionally injured boys who react with crying, hysteria, throwing toys, etc., are usually punished by the father while the mother speaks to the sad child and draws attention to some other activity or object in order to cheer them up, and if the children are scared, mothers attempt to protect them. Simply expressed, parents restrain children to clearly express what they feel. The father's is done with his authority, and the mother's with exaggerated sensibility. In today's education of children, it is essential that parents think about their children as individuals and then 
about their gender. Parents must be aware of children's uniqueness, diversity, and particularities that their child has. "Nourishment" or the so-called encouragement of rebellious behaviour in children leads to glorification only because he is a boy and is allowed to do anything. On the other hand, if the girls constantly remind us that boys have advantage, it will create the wrong attitude in life for the girl, which will be reflected in later life as harmful because it is consistent with prejudice.

The question that parents should ask themselves is "Why is this good / not good for my child?", and not "Why is this good / not good for my daughter / son?". In this way, parents nurture in their child qualities and benefits of both sexes, rather than classify them according to gender, a child is first and foremost a child. Parents must rise above all possible taboos, prejudices, and stereotypes towards their children by properly steering them and supporting them as unique, special, and different personalities. It is very important that parents (fathers in this case) be open to talking with their children and be as simple as possible. Children should be given only as much information as the one who exposes them (teacher or parent) at the time estimates that a child can understand.

\section{Mother as an educator}

Throughout history, along with social stratification, the family has experienced a series of transformations. The role of woman-mother is crucial for the formation and shaping of a family and a child. Depending on the degree of development of the society, as well as the people they belong to, the roles of women also change. Dilemmas of the most important role of women raise a number of stereotyped responses such as natural needs for women to give birth to children, carry out house chores, and raise children. In proportion to that role, the role of the female child in relation to the male child in the family is developed. A division of tasks appears within the family. This largely determines the position of women and children in the family. This position will change over time and will be completely transformed. They are economically dependent on their earner so that they are in a subordinate position. It is a patriarchal family where the husband is determined to decide on everything. The gender inequality is still present but to a much lesser extent. Today, when we talk about inequality between genders, we talk about gender discrimination. The position of women / mothers in rural and urban areas differs. A wife / mother is a basic factor in reproduction in both, rural and urban environment.

In the rural environment, women have roots in the traditional structure of authorities, such as her status belonging to the lowest social order. On the contrary, women in the urban living environment are not only the mother, but also the breadwinner of the family so they enjoy equal status with men.

"The position of women has changed over the centuries and will continue to change in the future. It depends on the development of mankind and other factors." (Tomic 1908: 4) Therefore, the role of a mother is defined as an educator, a person who directs, advises, teaches, transmits knowledge, expresses praise, but also punishes.

Today, mothers usually take care of the child's obligations "forcing them" to learn; they are among the first to receive unpleasant notices from the school and they 
recognize the problem of seeking a solution for the child, unlike the fathers who try to be friends and enrich the entertainment (sports) life of their child.

A special place in the upbringing and educational system is occupied by single mothers, whose number is on the increase. The educational goal of single mothers should be the same as if the child were growing up in a complete family.

The most complex relationship, but also the most difficult, is between mothers and adolescent daughters. The mother is the one who has a habit to control and has answers to all questions. In order to develop their personality, daughters have a greater need to protest, oppose, or rebel against maternal control.

Mothers, completely subconsciously, burden their children by creating a gap or seeking explanations without specifying reasons.

Educators have noted that the most common way of a mother's losing respect of her son is by the mother imposing too many demands (orders), and when the son resists, she just gives up or leaves everything for another day.

Male children need more independence and room for experimentation and research compared to females. On the one hand is a desire to prove what sons can do by themselves, while on the other hand, the desire of mothers to help their sons and that is consciously accepted by the son as a lack of confidence, which leads to "disobedience" by sons.

"When the son is odious or not willing to cooperate in response to the requests of his mother or her orders, the mother must be prepared to face up to his outpouring of fury and allow him a break. If a mother gives up easily or waits for the father to return home, she gives up control." (Gray 2001:315 / 317)

A father's behaviour toward the mother is of the utmost importance, because children will behave towards the mother similarly (i.e. towards their wives tomorrow). Children observe and imitate. Therefore, arguing spouses are not desirable in the presence of children. When the mother of the children speaks pejoratively of the father and complains about his behaviour, she unknowingly teaches her children that they too should not follow the father because he is not kind.

\section{Older family members and their influences on modern attitudes in education of children}

"Families in which parents live next to other adult family members can have both positive and negative influences on the formation of the character of the child." (Galevska 1961: 65). An old proverb says that a child without grandmothers and grandfathers is a child without a childhood. Grandparents as guardians and protectors of children can do best for them after the parents. This is particularly true at the present time when children's parents work outside the home." (Kačapor - Vilotijevic 2005: 472)

Older family members (grandmothers and grandfathers) allow much more freedom to the grandchildren than their parents if both "sides" want the best for the children. Educators believe that such fluctuations are acceptable, but the parent must not waver in the educational standards set by the grandmothers and grandfathers, and 
children must be aware of that. Good cooperation based on dialogue and agreement between the grandparents and parents is paramount. If grandparents do not live in the same household with their grandchildren, it is of great importance to the child to sleep over at their home, (i.e., sleep out of their own beds or parental home).

"Sometimes grandmothers and grandfathers tend to say they love their grandchildren more than their children. Despite the fact that grandparents may not have told their children they loved them, they now tell their grandchildren. It seems to them that they have a better understanding of the grandchildren, and that they have more patience and energy than they had for their children." (Holcer 2005: 127)

The safest free and always available child care service, of course, is the grandparents. If parents properly determine the cooperation with their parents about caring for the children, there will be enough time for activities that are extremely important to them and realized after their working hours.

The fact that the child will stay in fresh air, have a walk, stay warm and dry, have a good night story, and be rewarded for an educational story largely relieves parents so they can dedicate more time to their career.

A child who is surrounded by warmth, attention, and love grows into a confident, happy, and secure personality. Therefore, the love of grandmothers and grandfathers, in addition to parental love, is of great importance to the child. The patience that grandparents have reveals a true reservoir of tenderness; they allow and support their grandchildren to say and express what they want or feel, with full attention devoted to them. This is of great use in child development.

It is not good in these relationships if love and care are supplemented with allowing children to do whatever they want. This distorts the relationship between parents and grandparents, because disunity of educational goals appears between them. Parents become stricter and punish the children because they do not allow their children everything, while grandparents are tolerant and good because the child can express when, how, and where it wants.

Full of life experience and acquired wisdom, grandparents can transfer the same to their grandchildren, constantly encouraging the good; if a family has more children, they share their sweets and fruits with them, which greatly improves and helps in the formation of good relationships within the family.

"Some authors have attempted to classify the behaviour of grandparents to grandchildren. Thus, in his work "Family in Crisis", Mila Golden Vukov classifies their behaviour in 5 categories. Grandparents can be:

a) the "formal" role, because the parents look after children and grandparents have special time for grandchildren, and sometimes they have favourite grandchildren.

b) "parent substitutes" because they completely take care of the children as if they were their own.

c) "family wisdom"; authoritatively advise their children how to educate their own children.

d) "entertainers"; they spend time and play with the grandchildren.

e) "cold and distant persons" who occasionally visit the grandchildren; they are at a safe distance. "(Kačapor - Vilotijevic 2005: 473/474) 
However, the relations of these categories overlap and the categories interfere with each other.

\section{Younger members of the family and their impact on education of children}

When the family expands with the birth of a new (second) child, the attention of the adult family members inevitably focuses on the infant. An older child or children may experience the denial of love and affection from parents towards them. This can cause a reaction or a very substantial change in the behaviour of an older child. Children react differently to a new family member: hysterics and cry for every little thing, sometimes with the desire to injure the newborn, ignoring, return of some children to their behaviour in the earliest period of childhood such as imitating a baby and asking for full attention. If the difference between children is seven years or greater, it is natural that this kind of jealousy is absent, as it is believed that older children are better-formed and more mature.

A healthy and economically secure family is filled with love, respect, and understanding. The two main motives for the emergence of jealousy in young children within the family are:

- "taking away" of attention from older children by their parents after the arrival of a newborn in the family. The older child is no longer a source of admiration to the family because it grew up, and

- a sense rejection. Parents are often tired of older children attracting attention, which results in yelling, punishment, and threatening an older child. The child interprets this as rejection, and suffers.

In order to minimize the feelings of jealousy in the family, it is essential that parents:

- prepare the children for the arrival of the new baby in the family,

- talk very much, describing to the child that they are expecting a baby; they must describe the baby's abilities such as sleeping, crying, and feeding,

- explain to the child how it can help parents and his younger sister or brother. The tasks that the child is given will make the child feel important and create a feeling that without its help parents could not give enough attention to the little baby,

- praising the older child (because it is very necessary), especially when the child wants to play with its younger brother or sister.

The older the children are, the more the desire to compete is reinforced, and thus the rivalry. The period of jealousy between the children does not stop when the older child adjusts to the presence of a younger child. Their strife, jealousy, envy, and competition-rivalry may continue throughout adulthood. A parent must educate their children in a spirit of tolerance by teaching them to resolve their conflicts non-violently, but by agreement, and independently. If parents notice that an older child is abusing the younger one (physically or mentally), they must intervene and end the conflict. Even 
then, parents should not be the "investigating judge" and explore who initiated the quarrel.

When the children calm down and relax, a parent can talk to children calmly and authoritatively. It is important that through the process of education, parents treat their children as different personalities and realize that they do not compare. Frequent comparison and reference to the second child politely, gently, or calmly intensifies jealousy. It is better that a parent says and praises their differences of which children are proud and which were successful.

It is wrong if the parents expect the child to tattle on another such as what he/she was doing, where he/she left something, and how he/she behaved. We must encourage children to join a "team" because it strengthens their mutual relationships.

Parents' expectations that younger children should be as successful as an older sibling, or that the older child is a role model are wrong. In any case, it is not the youngest child's fault that it was born after the older siblings were.

Practice has shown that every newborn child in the family is easier to raise and educate, because having a rich experience gained with older children is an undeniable help.

It is essential that in educating their children, parents find the right measure in the evaluation of behaviour, stopping of hostilities and reaching a conclusion. Parents will best influence children with their personal examples.

It is of particular importance that the parents do not argue in front of their children, and that the children, rather than their goals to show that their partner is incorrect, are in the first place. If the mother affects the children to hide or carry out certain actions without the knowledge of the father, the children lose respect for the authority of the father, since they unconsciously or consciously accept that the mother is more important, for whose interests the children are committed to.

On the other hand, when it comes to conflict between parents and children, it is essential that parents keep together, rather than one of the parents representing their opinion by giving the child support behind the other's back.

Such education returns like a boomerang to the parents.

\section{Conclusion}

Parents are models of behaviour to their children. It is essential that parents, as a crucial factor that comes from the immediate environment, enable healthy development and support the adoption of habits and skills that are based on a democratic attitude towards themselves and the others.

In addition to parents, there are role models and influences involved in the education of children that come from the outside world, which is the wider environment. Choice of idols, which come into the family through mass media, peer groups, sports associations, non-government organizations and other humanitarian organizations, can have both a positive and negative impact on the educational habits of children. From the early childhood, a parent must make maximum effort to ensure children were properly 
brought up. Education of children promoting independent work starts during play. A game fulfils a child and the child feels its independence in making decisions. The dominance of one parent, fear of the father or mother, can have negative consequences in the education of children. Thus, it is important that the father and mother are equal; that their relationship is based on respect and love, and that they are open and honest in communicating with their children.

The influence of older family members, such as grandparents, is of great importance. There is a real danger of the grandparents being too lenient or too strict because they do not understand the needs of the younger generation. Support and love for children must be channelled by both parents in a harmonious relationship between all family members based on respect and openness.

\title{
Bibliography
}

Galevska, Rahela 1961. Moje dete i odrasli, Beograd: Narodna knjiga

Holcer, Jelena 2005. Uspešan roditelj - Uspešno dete, Beograd: Enco Book

Kačapor, Sait - Vilotijević, Nada 2005. Školska i porodična pedagogija, Užice: Bratis

Koković, Dragan 2000. Sociologija obrazovanja, Novi Sad: Univerzitet u Novom Sadu

Potkonjak, Nikola i grupa autora 1996. Pedagoški leksikon, Beograd: Zavod za udžbenike i nastavna sredstva

Potkonjak, Nikola - Šimleše, Petra 1989. Pedagoška enciklopedija 2, Beograd: Zavod za udžbenike i nastavna sredstva

Tomić, Jaša 1908. Predavanje "Žena i njeno pravo", Novi Sad: Štamparija dr. S. Miletića

Vasić, Vera - Jocić, Mirjana.1989. Školski rečnik, Novi Sad: Zavod za udžbenike Novi Sad

Metodički obzori 6(2011)2

Pregledni rad

UDK: 37.013 .2

Primljeno: 21. 10. 2010.

\section{KOMPATIBILONOST UŽE I ŠIRE SREDINE KAO NERAZDVOJIVIH FAKTORA SAVREMENE STRATEGIJE UČENJA I POUČAVANJA}

\author{
Bekir Makić, prof. \\ Internacionalni univerzitet \\ Novi Pazar (Serbia) \\ e-mail: bmakic@gmail.com
}

\section{Sa žetak}

Za pravilno vaspitanje deteta od krucijalnog značaja je ličnost roditelja, onih koji ga vaspitavaju, kojima je okružen u svom odrastanju. Na kvalitet duševnog i fizičkog zdravlja utiču oba roditelja. Njihov harmonični odnos, zasnovan na ljubavi i 
toleranciji, kod deteta direktno izaziva osećaj zadovoljstva i sreće. Što je porodica veća, brojnija, to je i odgovornost roditelja veća. Nove generacije, se ne vaspitavaju isključivo u okviru porodice. Dete, sticajem okolnosti, stupa u najrazličitije odnose, ostvarujući kontakte s društvom, preko vršnjaka u jaslicama, obdaništu, predškolskim ustanovama, u parku, a kasnije u školi, izbornoj grupi, sekcijama, klubovima. Pored roditelja i vršnjačkih grupa, na formiranje ličnosti deteta utiču i ostali članovi porodice: mlađa ili starija deca, baka i deka. Kao i roditelji, i oni vrše direktan, ali tako i indirektan uticaj na dete.

Ključne reči: porodica, roditelji, uža i šira sredina, uticaj, podrška, odnos (stav prema sebi i drugima) 